\title{
Molecular Mechanisms of Pituitary Cell Plasticity
}

\author{
Gwen V. Childs, Angus M. MacNicol and Melanie C. MacNicol* \\ Department of Neurobiology and Developmental Sciences, University of Arkansas for Medical Sciences, Little Rock, AR, \\ United States
}

\section{OPEN ACCESS}

Edited by:

Finn-Arne Weltzien,

Norwegian University of Life

Sciences, Norway

Reviewed by:

Giampaolo Trivellin

University of Milan, Italy

Anderson O. L. Wong,

The University of Hong Kong,

Hong Kong

*Correspondence:

Melanie C. MacNicol

macnicolmelanie@uams.edu

Specialty section:

This article was submitted to

Neuroendocrine Science,

a section of the journal

Frontiers in Endocrinology

Received: 04 June 2020

Accepted: 11 August 2020

Published: 10 September 2020

Citation:

Childs GV, MacNicol AM and MacNicol MC (2020) Molecular Mechanisms of Pituitary Cell Plasticity.

Front. Endocrinol. 11:656.

doi: 10.3389/fendo.2020.00656
The mechanisms that mediate plasticity in pituitary function have long been a subject of vigorous investigation. Early studies overcame technical barriers and challenged conceptual barriers to identify multipotential and multihormonal cell populations that contribute to diverse pituitary stress responses. Decades of intensive study have challenged the standard model of dedicated, cell type-specific hormone production and have revealed the malleable cellular fates that mediate pituitary responses. Ongoing studies at all levels, from animal physiology to molecular analyses, are identifying the mechanisms underlying this cellular plasticity. This review describes the findings from these studies that utilized state-of-the-art tools and techniques to identify mechanisms of plasticity throughout the pituitary and focuses on the insights brought to our understanding of pituitary function.

Keywords: pituitary, plasticity, multihormonal cells, multipotential, leptin, mRNA translation, Musashi, single cell

\section{INTRODUCTION}

The pituitary system orchestrates appropriate behavioral responses to fluctuating physiological and/or pathological signals, through controlled production and secretion of diverse signaling peptide hormones. The levels of hormone that must be secreted to meet effective serum levels for the intended response, is vast relative to the small size of the pituitary itself, and this defined size limits the number of cells that can be utilized in effecting any one of the many responses. These opposing challenges of limited cell numbers and diverse, large required outputs are resolved through plasticity in allocation of cell resources to each particular function (see Figure 1). The mechanisms controlling pituitary cell plasticity are a source of tremendous interest since these mechanisms first began to be revealed and evidence of malfunction in pituitary plasticity under diverse genetic and disease states has further motivated study to understand these mechanisms [for reviews see $(1,2)$ ]. Over the last several decades, an ongoing procession of cutting edge, novel techniques have been developed and embraced in the effort to understand pituitary function and plasticity. In this mini review, we identify the multiple fortuitous links that have occurred between the need for information about a particular aspect of pituitary function and the identification, discovery and/or development of a new technique or tool that provided that information. We follow the pathway of discovery made with early cell microscopy 
A

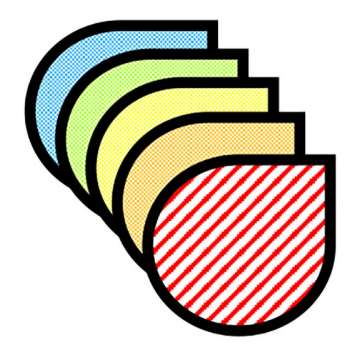

Starting populations
B

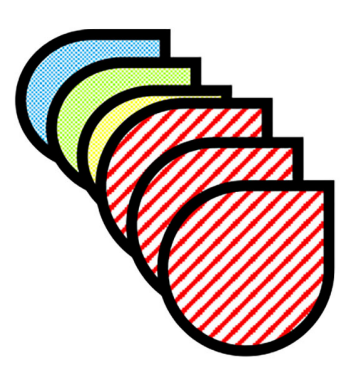

Restructured populations

FIGURE 1 | Pituitary cell populations are restructured in response to physiological stimuli and pathological stressors. (A) The pituitary is comprised of multiple distinct functional cell types (designated by different image fill patterns). (B) In response to physiological stimuli or pathological stress, the pituitary cell populations undergo restructuring. The double arrows imply the potential reversibility of this process. See text for details and relevant references.

technologies through the ongoing development and utilization of complex and specific animal models to the emerging utilization of molecular and computational techniques that together identify cell-specific information. We will primarily focus on discoveries made through those tools and techniques that we have utilized ourselves, with the expectation that this overview will give a representative example of the pathways that have led to our current understanding of pituitary plasticity.

\section{BREAKTHROUGH DISCOVERIES; VISUALIZATION LEADING TO CELL IDENTIFICATION}

The development of multiplexing technologies, simultaneously identifying multiple proteins and/or both proteins and mRNAs in the same cell population enabled a conceptual breakthrough in identification of the mechanisms of pituitary plasticity. The identification of more than one hormone in a single cell or the identification of cell surface activating receptors and distinct intracellular hormones in the same cell, suggested the presence of multipotential cells, a novel concept in the face of an existing paradigm of pituitary organization that indicated each hormone is produced by a dedicated cell population (3). The experimental proof of bona fide multipotential cells, as opposed to the uptake of proteins to one cell type from another cell type, required development and utilization of complex staining protocols along with novel microscopy technologies (4). These early studies, including those utilizing biotin-streptavidin directed staining, in situ hybridization, and immunogold electron microscopy, enabled identification of specific populations within the mature adult pituitary that express the mRNA, receptors and/or hormones indicative of multiple distinct cell types. Studies using calcium signaling identified populations of pituitary cells that appeared to be fully differentiated toward a specific cell type, yet retained the capacity to respond to multiple releasing hormones of other distinct cell types (5). These findings introduced the concept of multihormonal/multipotential cells within the adult pituitary, with the capacity to contribute to functional plasticity through generation of whichever cell type was needed to serve hormone demand. The origin of these multipotential cells continues to hold fascination in the study of pituitary plasticity. The mechanisms by which they arise, either from an existing subpopulation of immature progenitor cells or through a transdifferentiation of existing hormone-producing, mature cells remains an open question (6-8) (see Figure 2).

As the identification of multipotential/multihormonal cell types was hampered by technical barriers in distinguishing these cells from their monohormonal counterparts, so conceptual barriers further occluded their identification. Models of pituitary organization based upon embryological studies showed the ventral to dorsal gradients of tissue differentiation factors including Bmp2 and Gata2, that stimulate generation of gonadotropes in ventral regions and restrict expression of the opposing differentiation factor Poulf1 (also named Pit-1), which is required for the generation of somatotropes, thyrotropes and lactotropes $(9,10)$. The decreased levels of Bmp2 in dorsal regions is thus required to allow the differentiation of somatotropes as Poulf1 binds to Gata2 and prevents it from activating factors needed for gonadotrope development. These findings together support a model in which monohormonal somatotropes and gonadotropes develop in separate regions of the embryonic pituitary with the balance between expression of Poulf1 and Gata2 restricting specification of each cell type (11-13). This developmental model appeared to preclude the presence of cells that produce multiple hormones, such as those that would require both Pou1f1 and Gata2, e.g., somatotogonadotropes (14).

Continued efforts in the field, however, revealed a model in which pituitary plasticity utilizes all members of a cell population, including multihormonal/multipotential subtypes, in response to challenges by stimuli that require multiple hormone responses. This coordinated multi cell-type response was demonstrated through affinity cytochemical studies showing the estradiol-mediated increase in gonadotropin releasing 


\section{A

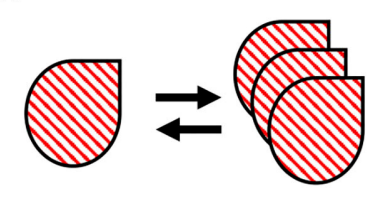

Proliferation of mature cells
B

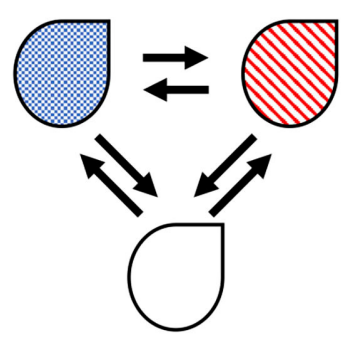

Transdifferentiation of mature cells
C

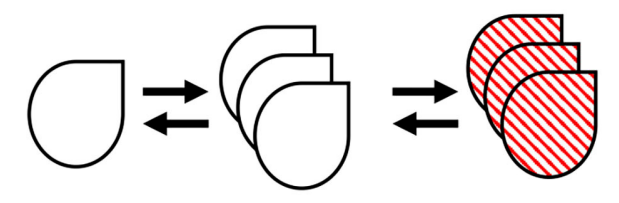

Activation/differentiation of stem/progenitor cells

FIGURE 2 | Cellular mechanisms that may contribute to pituitary population restructuring. There is evidence that pituitary populations undergo restructuring through multiple cellular mechanisms including (A) mitotic proliferation of existing hormone cells, (B) transdifferentiation of mature hormone cells and (C) activation and differentiation of stem/progenitor cells. The double arrows imply a potential reversibility of these cellular processes. See text for details and relevant references.

hormone receptor (GnRHR) production by somatotropes, as well as by gonadotropes, with the somatotropes defined by their expression of growth hormone $(\mathrm{GH})$ protein and mRNA (15). Gonadotropin releasing hormone ( $\mathrm{GnRH}$ ) was thus found to stimulate an increase in production of the "gonadotropespecific" hormones, luteinizing hormone (LH) and folliclestimulating hormone (FSH) by both gonadotropes and a subset of somatotropes/somatogonadotropes to support the high levels of $\mathrm{LH}$ and FSH that are needed to effect estrous cycle surges. A role for multihormonal cells in mediating pituitary plasticity was further proposed to facilitate the high levels of adrenocorticotropic hormone $(\mathrm{ACTH})$, beta-endorphin, and thyroid stimulating hormone (TSH) that are required for the response to extreme or prolonged cold (16). The coordination of these multihormonal responses appear to require contributions from cells capable of producing multiple hormones in response to distinct neuropeptide secretagogues as has been demonstrated through cold stress-induced, arginine vasopressin (AVP) stimulation of "thyrocorticotropes" to produce both ACTH and TSH $(17,18)$. As these cells also respond to thyrotropin-releasing hormone (TRH) and corticotropinreleasing hormone $(\mathrm{CRH})$, both of which enhance AVP receptor expression, these multipotential target cells would serve to amplify the pituitary response to stress.

The identification of mechanisms underlying pituitary functional plasticity has benefitted from the development and use of a number of techniques to isolate distinct pituitary cell subpopulations. These are reviewed in a recent publication (19). One early method developed in our laboratory included counterflow elutriation that took advantage of the different size and morphologies of distinct pituitary cell types to obtain subpopulations that were $90 \%$ pure (20). However, higher levels of purity are obtained with approaches that involve the expression of cell type-specific fluorescent proteins such as the enhanced green fluorescent protein (eGFP), linked to the gene promoter of a cell-type specific protein, such as somatotrope $\mathrm{GH}$, enabled the use of fluorescent activated cell sorting technologies (FACS) that provide a pure population of live cells for downstream analyses (21). Development of pituitary cell-lineage tracing mouse models have identified a population of Sox2-expressing stem cells in the adult pituitary that can differentiate to produce all hormone-expressing cell types (22-26). Although activation of this cell population has been observed under conditions of acute experimental stress, e.g., hormone cell type-specific cell oblation and organ loss, the extent to which this mechanism contributes to pituitary homeostasis and functional plasticity is unclear (27). Adult stem cells have also been implicated in mediating pituitary neo-plastic growth, and this pathological aspect of pituitary plasticity has been extensively covered in recent excellent reviews $(28,29)$.

Continuing developments in microscopy, including the use of live cell imaging and electrophysiological tools, along with the development of analysis software has further enabled the identification of pituitary cell morphology plasticity and the observation of pituitary cell process motility and remodeling (30). Together, these cell properties have been shown to contribute to the formation of complex, threedimensional heterotypic and homotypic pituitary cell networks that functionally contribute to plasticity of response $(31,32)$. Identification of the distinct subpopulations within a specific hormone cell type has been further facilitated through use of teleost transgenic models that demonstrate the role of heterotypic network communication in mediating gonadotrope function and plasticity (33). The ongoing development of pituitary tissue and cell culture techniques and the in vitro growth of pituitary stem/progenitor cells as "organoids" is directed toward development of an experimental model that is being utilized to address mechanisms of pituitary function that occur on an intermediate timescale, between the short term of cell culture and the lifetime of animal models (34-36). Organoid model developments include the use of human induced pluripotent stem cells (iPSCs) and the co-differentiation of hypothalamic and pituitary tissues in patient-specific organoids $(37,38)$. These human cell-based models complement the use of transgenic models in revealing the mechanisms underlying pituitary cell plasticity. 


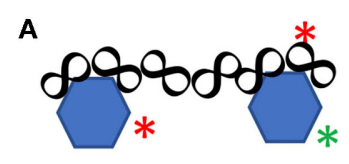

$\uparrow \downarrow$

Chromatin modification

B

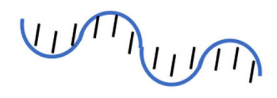

$\uparrow \downarrow$ c

$\square$

$\uparrow$

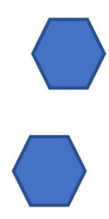

Protein levels
D

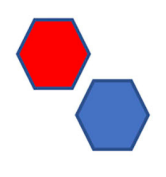

$\uparrow \downarrow$

Protein activity

FIGURE 3 | Molecular mechanisms that may contribute to pituitary population restructuring. Pituitary cell populations may utilize multiple molecular mechanisms for restructuring including (A) chromatin remodeling (B) gene transcriptional control (C) control of mRNA translation to protein and (D) control of protein function. The double arrows indicate the potential for both activating (positive) and inhibitory (negative) effects upon these molecular mechanisms. See text for details and relevant references.

\section{CONTINUING DISCOVERIES; MECHANISMS MEDIATING CELL PLASTICITY}

The utilization of transgenic animal models has greatly facilitated the study of pituitary function and plasticity. Many diverse, genomic models have been employed in identification of the roles of specific mediators of pituitary physiology and disease through the identification of effects upon whole animal physiology [for review see (2)]. Through the use of genetic models of pituitary cell type-specific leptin receptor knock-out, we have identified the mechanisms by which energy stores, as indicated through serum leptin signaling, influence pituitary function to optimize growth and reproduction. Findings from these studies have revealed the direct influence that leptin signaling has upon pituitary cell plasticity and the maturation required for hormone protein synthesis and secretion from pituitary somatotropes and pituitary gonadotropes $(19,39)$. Findings from these studies include the observation of decreased levels of growth hormone gene transcription ( $G h$ mRNA) in pituitary somatotropes under conditions of loss of leptin signaling to the pituitary, thus indicating a link between leptin signaling to the pituitary and specific activator (s) of the Gh gene regulatory machinery (19).

Gene expression detection techniques have further resulted in the discovery of the absence of altered gene transcription under conditions in which it is expected, e.g., under conditions in which an increase in levels of GnRHR is observed in pituitary gonadotropes in response to leptin stimulation, that is not coincident with an increase in Gnrhr mRNA (39). This observed lack of concordance between changes in protein levels and changes in cognate mRNA levels suggests that a post-transcriptional mechanism mediates this regulatory process (40). We have recently found that the translation of the Gnrhr mRNA is repressed through the action of the RNA binding protein Musashil through direct association with the Gnrhr mRNA 3 untranslated region (41). Leptin stimulation is proposed to inhibit Musashil function, allowing de-repression and translation of the Gnrhr mRNA $(39,41)$. A recent study has demonstrated an opposing role for the RNA binding protein ELAVL1 through the post-transcriptional enhancement of Grrhr mRNA stability (42). Since Musashi1 and ELAVL1 are found in common mRNA ribonucleoprotein complexes, Musashil and ELAVL1 may be coordinately regulated to differentially govern Gnrhr mRNA translation and thus gonadotrope remodeling throughout the estrus cycle (43). Several recent transcriptomics analyses of the pituitary at the cell type-specific and at the single cell level, have revealed an extraordinary level of variation in cell identity (44-47). The potential for plasticity at the cellular level, as defined by expression of genes associated with multiple hormone-producing cell types has been identified in a significant percentage of adult pituitary cells (47). These technologies greatly contribute to the comprehensive development of a model of pituitary cell functional plasticity. Findings from these analyses have definitively identified a multihormonal-expressing population within the adult pituitary that undergoes a high level of plasticity in hormone gene expression in response to the physiological stresses (47). The relevance of these data to mechanisms of pituitary plasticity will continue to be revealed as new 'omics data are obtained and bioanalysis tools are developed $(48,49)$ (see Figure 3).

\section{CONCLUSIONS AND FUTURE DIRECTIONS; BIG DATA TO MOLECULAR MANIPULATION}

The understanding of pituitary function is relevant to diverse biomedical fields. Pituitary plasticity is fundamental to reproductive and endocrine function and impinges upon the control of metabolic disease, cancer and cell replacement therapies. From early imaging and cell morphology assays to current 'omics analyses, the array of methodologies directed toward an understanding of pituitary function stands as an exemplar of biomedical research capabilities (see Figure 4). The study of pituitary plasticity continues to utilize state of the art and emerging tools that provide data relevant to endocrine function and disorders over a wide biological scale from whole population patient data sets to molecular mechanisms revealed by novel animal models and single cell analyses. Ongoing and future studies are expected to combine targets revealed through these analyses with experimental interventions $(35,50)$. The recognition of the limitations of existing methods has driven 


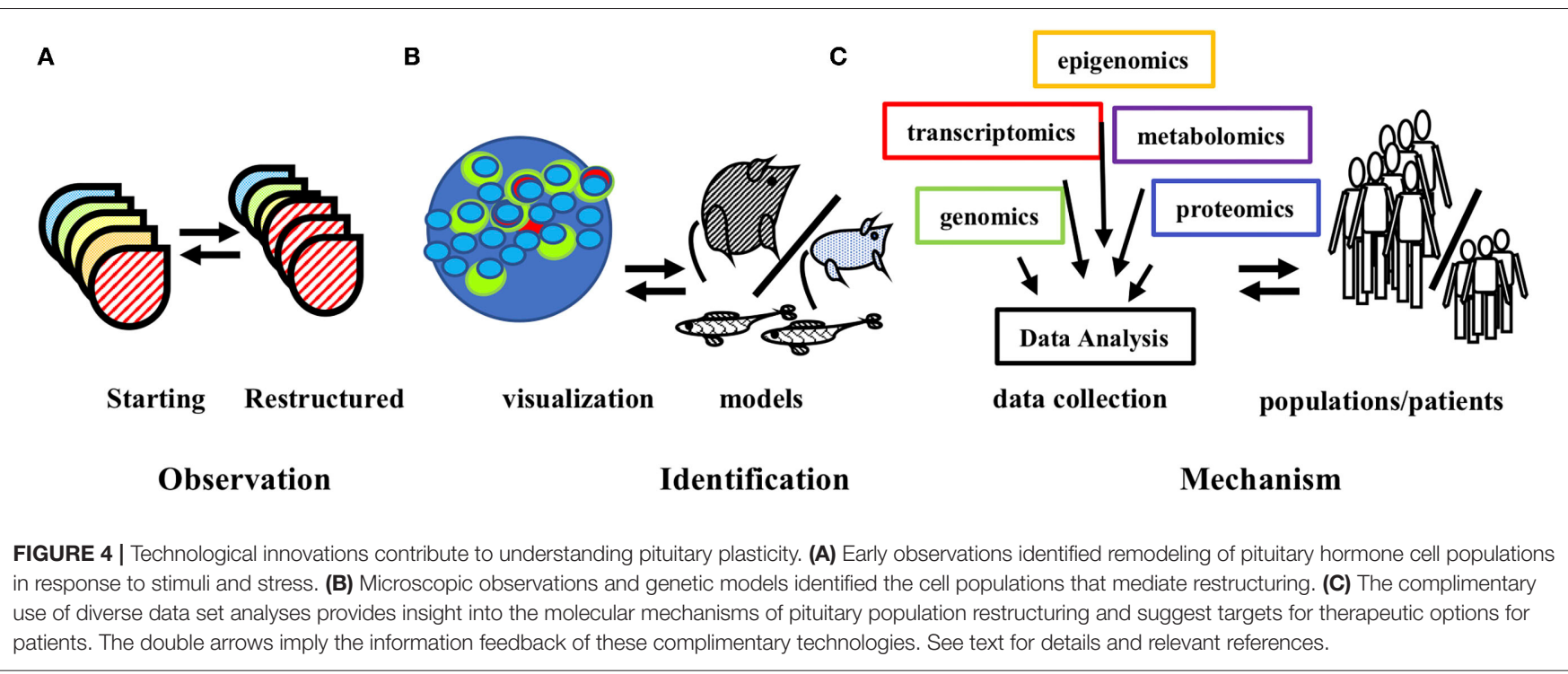

the development and use of novel technologies in pursuit of an understanding pituitary function. Similar to the creative courage that is required to propose new hypotheses, so, experimental courage is often required to test them; the employment of these together, will ensure that our ongoing investigations of pituitary function and plasticity will continue in new and exciting directions.

\section{AUTHOR CONTRIBUTIONS}

GC and MM planned and wrote the paper. MM designed the figures. GC, AM, and MM edited the paper. All authors contributed to the article and approved the submitted version.

\section{REFERENCES}

1. Le Tissier P, Campos P, Lafont C, Romano N, Hodson DJ, Mollard P. An updated view of hypothalamic-vascular-pituitary unit function and plasticity. Nat Rev Endocrinol. (2017) 13:257-67. doi: 10.1038/nrendo.2016.193

2. Fontaine R, Ciani E, Haug TM, Hodne K, Ager-Wick E, Baker $\mathrm{DM}$, et al. Gonadotrope plasticity at cellular, population and structural levels: a comparison between fishes and mammals. Gen Comp Endocrinol. (2020) 287:113344. doi: 10.1016/j.ygcen.2019.11 3344

3. Zhu X, Gleiberman AS, Rosenfeld MG. Molecular physiology of pituitary development: signaling and transcriptional networks. Physiol Rev. (2007) 87:933-63. doi: 10.1152/physrev.00006.2006

4. Childs GV, Lloyd JM, Unabia G, Gharib SD, Wierman ME, Chin WW. Detection of luteinizing hormone beta messenger ribonucleic acid (RNA) in individual gonadotropes after castration: use of a new in situ hybridization method with a photobiotinylated complementary RNA probe. Mol Endocrinol. (1987) 1:926-32. doi: 10.1210/mend-1-12-926

5. Nunez L, Villalobos C, Senovilla L, Garcia-Sancho J. Multifunctional cells of mouse anterior pituitary reveal a striking sexual dimorphism. J Physiol. (2003) 549(Pt 3):835-43. doi: 10.1113/jphysiol.2003.040758

6. Vidal S, Horvath E, Kovacs K, Cohen SM, Lloyd RV, Scheithauer BW. Transdifferentiation of somatotrophs to thyrotrophs in the pituitary of

\section{FUNDING}

This study was funded by National Institutes of Health, 1R01DK113776-01 (GC, AM, and MM) and R01HD093461 (AM, GC and MM), and R01HD087057 (GC and AM).

\section{ACKNOWLEDGMENTS}

The brief format of this review necessitated a limited representation of the field, and we apologize to the authors of the many studies that were not presented. patients with protracted primary hypothyroidism. Virchows Arch. (2000) 436:43-51. doi: 10.1007/PL00008197

7. Childs GV. Development of gonadotropes may involve cyclic transdifferentiation of growth hormone cells. Arch Physiol Biochem. (2002) 110:42-9. doi: 10.1076/apab.110.1.42.906

8. Radian S, Coculescu M, Morris JF. Somatotroph to thyrotroph cell transdifferentiation during experimental hypothyroidism a light and electron-microscopy study. J Cell Mol Med. (2003) 7:297-306. doi: 10.1111/j.1582-4934.2003.tb00230.x

9. Simmons DM, Voss JW, Ingraham HA, Holloway JM, Broide RS, Rosenfeld MG, et al. Pituitary cell phenotypes involve cell-specific Pit1 mRNA translation and synergistic interactions with other classes of transcription factors. Genes Dev. (1990) 4:695-711. doi: 10.1101/gad.4. 5.695

10. Treier M, Gleiberman AS, O'Connell SM, Szeto DP, McMahon JA, McMahon AP, et al. Multistep signaling requirements for pituitary organogenesis in vivo. Genes Dev. (1998) 12:1691-704. doi: 10.1101/gad.12.11. 1691

11. Dasen JS, O'Connell SM, Flynn SE, Treier M, Gleiberman AS, Szeto DP, et al. Reciprocal interactions of Pit1 and GATA2 mediate signaling gradient-induced determination of pituitary cell types. Cell. (1999) 97:587-98. doi: 10.1016/S0092-8674(00)80 770-9 
12. Childs GV. Growth hormone cells as co-gonadotropes: partners in the regulation of the reproductive system. Trends Endocrinol Metab. (2000) 11:168-75. doi: 10.1016/S1043-2760(00)00252-6

13. Scully KM, Rosenfeld MG. Pituitary development: regulatory codes in mammalian organogenesis. Science. (2002) 295:22315. doi: $10.1126 /$ science. 1062736

14. Childs GV, Unabia G, Wu P. Differential expression of growth hormone messenger ribonucleic acid by somatotropes and gonadotropes in male and cycling female rats. Endocrinology. (2000) 141:1560-70. doi: 10.1210/endo.141.4.7429

15. Childs GV, Unabia G, Miller BT. Cytochemical detection of gonadotropin-releasing hormone-binding sites on rat pituitary cells with luteinizing hormone, follicle-stimulating hormone, and growth hormone antigens during diestrous up-regulation. Endocrinology. (1994) 134:1943-51. doi: 10.1210/endo.134.4.8137763

16. Sasaki F, Wu P, Rougeau D, Unabia G, Childs GV. Cytochemical studies of responses of corticotropes and thyrotropes to cold and novel environment stress. Endocrinology. (1990) 127:285-97. doi: 10.1210/endo-127-1-285

17. Childs GV, Westlund KN, Unabia G. Characterization of anterior pituitary target cells for arginine vasopressin: including cells that store adrenocorticotropin, thyrotropin-beta, and both hormones. Endocrinology. (1989) 125:554-9. doi: 10.1210/endo-125$1-554$

18. Wu P, Childs GV. Cold and novel environment stress affects AVP mRNA in the paraventricular nucleus, but not the supraoptic nucleus: an in situ hybridization study. Mol Cell Neurosci. (1990) 1:233-49. doi: 10.1016/1044-7431(90)90 006-P

19. Odle AK, Allensworth-James ML, Akhter N, Syed M, Haney AC, MacNicol $\mathrm{M}$, et al. A sex-dependent, tropic role for leptin in the somatotrope as a regulator of POU1F1 and POU1F1-dependent hormones. Endocrinology. (2016) 157:3958-71. doi: 10.1210/en.2016-1472

20. Childs GV, Lloyd JM, Rougeau D, Unabia G. Enrichment of corticotropes by counterflow centrifugation. Endocrinology. (1988) 123:2885-95. doi: 10.1210/endo-123-6-2885

21. Magoulas C, McGuinness L, Balthasar N, Carmignac DF, Sesay AK, Mathers KE, et al. A secreted fluorescent reporter targeted to pituitary growth hormone cells in transgenic mice. Endocrinology. (2000) 141:46819. doi: 10.1210/endo.141.12.7828

22. Andoniadou CL, Matsushima D, Mousavy Gharavy SN, Signore M, Mackintosh AI, Schaeffer M, et al. Sox2(+) stem/progenitor cells in the adult mouse pituitary support organ homeostasis and have tumor-inducing potential. Cell Stem Cell. (2013) 13:433-45. doi: 10.1016/j.stem.2013.0 7.004

23. Rizzoti K, Akiyama H, Lovell-Badge R. Mobilized adult pituitary stem cells contribute to endocrine regeneration in response to physiological demand. Cell Stem Cell. (2013) 13:419-32. doi: 10.1016/j.stem.2013.07.006

24. Garcia-Lavandeira M, Diaz-Rodriguez E, Bahar D, Garcia-Rendueles AR, Rodrigues JS, Dieguez C, et al. Pituitary cell turnover: from adult stem cell recruitment through differentiation to death. Neuroendocrinology. (2015) 101:175-92. doi: 10.1159/000375502

25. Mariniello K, Ruiz-Babot G, McGaugh EC, Nicholson JG, Gualtieri A, GastonMassuet C, et al. Stem cells, self-renewal, and lineage commitment in the endocrine system. Front Endocrinol. (2019) 10:772. doi: 10.3389/fendo.2019.0 0772

26. Cox B, Roose H, Vennekens A, Vankelecom H. Pituitary stem cell regulation: who is pulling the strings? J Endocrinol. (2017) 234:R135R58. doi: 10.1530/JOE-17-0083

27. Roose H, Cox B, Boretto M, Gysemans C, Vennekens A, Vankelecom H. Major depletion of SOX2(+) stem cells in the adult pituitary is not restored which does not affect hormonal cell homeostasis and remodelling. Sci Rep. (2017) 7:16940. doi: 10.1038/s41598-017-16 796-2

28. Haston S, Manshaei S, Martinez-Barbera JP. Stem/progenitor cells in pituitary organ homeostasis and tumourigenesis. J Endocrinol. (2018) 236:R1R13. doi: 10.1530/JOE-17-0258

29. Wurth R, Thellung S, Corsaro A, Barbieri F, Florio T. Experimental evidence and clinical implications of pituitary adenoma stem cells. Front Endocrinol. (2020) 11:54. doi: 10.3389/fendo.2020.0 0054

30. Lafont C, Desarmenien MG, Cassou M, Molino F, Lecoq J, Hodson D, et al. Cellular in vivo imaging reveals coordinated regulation of pituitary microcirculation and GH cell network function. Proc Natl Acad Sci USA. (2010) 107:4465-70. doi: 10.1073/pnas.0902599107

31. Mollard P, Hodson DJ, Lafont C, Rizzoti K, Drouin J. A tridimensional view of pituitary development and function. Trends Endocrinol Metab. (2012) 23:261-9. doi: 10.1016/j.tem.2012.02.004

32. Edwards BS, Clay CM, Ellsworth BS, Navratil AM. Functional role of gonadotrope plasticity and network organization. Front Endocrinol. (2017) 8:223. doi: $10.3389 /$ fendo.2017.0 0223

33. Hodne K, Fontaine R, Ager-Wick E, Weltzien FA. Gnrh1-induced responses are indirect in female medaka fsh cells, generated through cellular networks. Endocrinology. (2019) 160:3018-32. doi: 10.1210/en.2019-00595

34. Suga H, Kadoshima T, Minaguchi M, Ohgushi M, Soen M, Nakano $\mathrm{T}$, et al. Self-formation of functional adenohypophysis in threedimensional culture. Nature. (2011) 480:57-62. doi: 10.1038/nature1 0637

35. Zimmer B, Piao J, Ramnarine K, Tomishima MJ, Tabar V, Studer L. Derivation of diverse hormone-releasing pituitary cells from human pluripotent stem cells. Stem Cell Rep. (2016) 6:858-72. doi: 10.1016/j.stemcr.2016.05.005

36. Cox B, Laporte E, Vennekens A, Kobayashi H, Nys C, Van Zundert I, et al. Organoids from pituitary as a novel research model toward pituitary stem cell exploration. J Endocrinol. (2019) 240:287-308. doi: 10.1530/JOE-18-0462

37. Kasai T, Suga H, Sakakibara M, Ozone C, Matsumoto R, Kano $\mathrm{M}$, et al. Hypothalamic contribution to pituitary functions is recapitulated in vitro using $3 \mathrm{~d}$-cultured human ips cells. Cell Rep. (2020) 30:18-24 e5. doi: 10.1016/j.celrep.2019.1 2.009

38. Matsumoto R, Suga H, Aoi T, Bando H, Fukuoka H, Iguchi G, et al. Congenital pituitary hypoplasia model demonstrates hypothalamic OTX2 regulation of pituitary progenitor cells. J Clin Invest. (2020) 130:64154. doi: 10.1172/JCI127378

39. Akhter N, CarlLee T, Syed MM, Odle AK, Cozart MA, Haney AC, et al. Selective deletion of leptin receptors in gonadotropes reveals activin and GnRH-binding sites as leptin targets in support of fertility. Endocrinology. (2014) 155:4027-42. doi: 10.1210/en.2014-1132

40. Kim T, Do MH, Lawson MA. Translational control of gene expression in the gonadotrope. Mol Cell Endocrinol. (2014) 385:78-87. doi: 10.1016/j.mce.2013.09.007

41. Odle AK, Benes H, Melgar Castillo A, Akhter N, Syed M, Haney A, et al. Association of Gnrhr mRNA with the stem cell determinant musashi: a mechanism for leptin-mediated modulation of GnRHR expression. Endocrinology. (2018) 159:883-94. doi: 10.1210/en.2017-0 0586

42. Terasaka T, Kim T, Dave H, Gangapurkar B, Nicholas DA, Munoz $\mathrm{O}$, et al. The RNA-binding protein ELAVL1 regulates gnrh receptor expression and the response to GnRH. Endocrinology. (2019) 160:19992014. doi: 10.1210/en.2019-00203

43. MacNicol AM, Odle AK, Childs GV. ELAVL1 elevates insights: the ups and downs of regulated mRNA translation in the control of gonadotropin release. Endocrinology. (2019) 160:2466-8. doi: 10.1210/en.2019-00524

44. Qiao S, Nordstrom K, Muijs L, Gasparoni G, Tierling S, Krause E, et al. Molecular plasticity of male and female murine gonadotropes revealed by mRNA sequencing. Endocrinology. (2016) 157:1082-93. doi: 10.1210/en.2015-1836

45. Cheung LYM, George AS, McGee SR, Daly AZ, Brinkmeier ML, Ellsworth BS, et al. Single-cell rna sequencing reveals novel markers of male pituitary stem cells and hormone-producing cell types. Endocrinology. (2018) 159:3910 24. doi: 10.1210/en.2018-00750

46. Fletcher PA, Smiljanic K, Maso Previde R, Iben JR, Li T, Rokic MB, et al. Cell type- and sex-dependent transcriptome profiles of rat anterior pituitary cells. Front Endocrinol. (2019) 10:623. doi: 10.3389/fendo.2019.00623

47. Ho Y, Hu P, Peel MT, Chen S, Camara PG, Epstein DJ, et al. Single-cell transcriptomic analysis of adult mouse pituitary reveals sexual dimorphism and physiologic demand-induced cellular 
plasticity. Protein Cell. (2020) 11:565-83. doi: 10.1007/s13238-020-00 705-x

48. Pinzariu O, Georgescu B, Georgescu CE. Metabolomics-a promising approach to pituitary adenomas. Front Endocrinol. (2018) 9:814. doi: 10.3389/fendo.2018.00814

49. Yelamanchi SD, Tyagi A, Mohanty V, Dutta P, Korbonits M, Chavan S, et al. Proteomic analysis of the human anterior pituitary gland. OMICS. (2018) 22:759-69. doi: 10.1089/omi.2018.0160

50. Bartfeld S, Clevers H. Stem cell-derived organoids and their application for medical research and patient treatment. J Mol Med (Berl). (2017) 95:72938. doi: 10.1007/s00109-017-1531-7
Conflict of Interest: The authors declare that the research was conducted in the absence of any commercial or financial relationships that could be construed as a potential conflict of interest.

Copyright (c) 2020 Childs, MacNicol and MacNicol. This is an open-access article distributed under the terms of the Creative Commons Attribution License (CC BY). The use, distribution or reproduction in other forums is permitted, provided the original author(s) and the copyright owner(s) are credited and that the original publication in this journal is cited, in accordance with accepted academic practice. No use, distribution or reproduction is permitted which does not comply with these terms. 